\title{
Implementasi Teknologi Internet of Things Pada Sistem Pemantauan Kebocoran Gas LPG dan Kebakaran Menggunakan Database Pada Google Firebase
}

\author{
Abi Sabila Mustaqim ${ }^{1}$, Danny Kurnianto ${ }^{2 *}$, Fikra Titan Syifa ${ }^{3}$ \\ ${ }^{1,23}$ Fakultas Teknik Telekomunikasi dan Elektro, Institut Teknologi Telkom Purwokerto \\ Jl. D.I Panjaitan No.128 Purwokerto, Indonesia \\ *Corresponding Author, email:dannykurnianto@ittelkom-pwt.ac.id
}

\begin{abstract}
Kebakaran akibat kebocoran gas Liquefied Petroleum Gas (LPG) merupakan salah satu bencana yang masih sering terjadi di masyarakat. Ketidaktahuan masyarakat akan standar keamanan dalam menggunakan tabung gas LPG menjadi salah satu penyebabnya. Sebenarnya, kebakaran dapat dicegah jika pada saat terjadi kebocoran gas LPG dapat dideteksi lebih awal. Oleh karena itu diperlukan suatu sistem yang dapat memantau kondisi kebocoran gas dan kebakaran dari jarak jauh. Teknologi Internet of Things (IoT) dapat diterapkan pada sistem pemantauan ini sehingga informasi kebocoran gas LPG maupun kebakaran dapat dipantau dari jarak jauh. Sistem pemantauan kebocoran Gas LPG dan Kebakaran Berbasis Internet of Things (IoT) merupakan sebuah konsep yang memanfaatkan konektivitas internet antara perangkat smartphone yang tersambung dengan perangkat sensor. Perangkat yang digunakan untuk mendukung sistem ini diantaranya adalah NodeMCU ESP8266 sebagai mikrokontroler dan sebagai penghubung ke internet, sensor gas MQ-6 dan flame sensor sebagai sensor pendeteksi kebocoran gas dan kebakaran, buzzer sebagai alarm, dan kipas sebagai penetral kadar gas dalam ruangan. Data yang diperoleh oleh sensor akan diunggah ke database melalui internet dan dapat diakses melalui sebuah aplikasi android. Hasil dari perancangan menunjukkan bahwa aplikasi android dapat menampilkan notifikasi kepada pengguna pada saat terjadi kebocoran gas maupun kebakaran. Pada pengujian kinerja transmisi data menunjukkan hasil bahwa waktu tunda (delay) transmisi data tertinggi adalah sebesar 64,61 detik dan waktu tunda (delay) terendah 61,56 detik, nilai throughput tertinggi sebesar 747,6 bit/second dan nilai terendah sebesar $285,4 \mathrm{bit} /$ second.
\end{abstract}

Kata kunci: Internet of things, kebocoran gas LPG, NodeMCU ESP8266, Google Firebase

\begin{abstract}
Abstrak-Fire due to Liquefied Petroleum Gas (LPG) gas leak is one of the disasters that still often occurs in the community. Community ignorance of safety standards in using LPG gas is one reason. Fires can be prevented if at the time of the LPG gas leak can be detected earlier. Therefore we need a system that can monitor the condition of gas leaks and fires remotely. Internet of things (IoT) technology can be applied to this monitoring system so that information on LPG gas leaks and fires can be monitored remotely. The Internet of Things (IoT) based LPG and Fire leak monitoring system is a concept that utilizes internet connectivity between smartphone devices connected to sensor devices. The devices used to support this system include NodeMCU ESP8266 as a microcontroller and as a liaison to the internet, MQ-6 gas sensors and flame sensors as sensors for detecting gas and fire leaks, buzzers as alarms, and fans as neutralizing gas levels in the room. Data obtained by the sensor will be uploaded to the database via the internet and can be accessed through an android application. The results of the design show that the android application can display notifications when a gas leak or fire occurs. In testing the performance of data transmission, the results show that the highest data transmission delay is 64,61 seconds, and the lowest delay time is 61,56 seconds, the highest throughput value is 747,6 bits/second, and the lowest value is 285,4 bits/second.
\end{abstract}

Keyword: Internet of things, LPG gas leak, NodeMCU ESP8266, Google Firebase

(C) 2020 Elektron Jurnal Ilmiah

\section{PENDAHULUAN}

Semenjak dihapuskannya subsidi minyak tanah oleh pemerintah, masyarakat mulai bermigrasi untuk menggunakan tabung gas Liquefied Petroleum Gas (LPG) untuk keperluan rumah tangga [1]. Gas LPG merupakan gas yang terbentuk dari hasil produksi kilang minyak dan kilang gas. Gas LPG banyak dimanfaatkan oleh masyarakat untuk berbagai kepentingan, diantaranya untuk industri, komersial dan rumah tangga. Gas LPG dapat berdampak negatif terhadap kesehatan manusia bahkan menimbulkan kerugian yang cukup besar apabila tidak digunakan dengan hati-hati, terutama bila tidak diketahui telah terjadi kebocoran dari tabung atau tempat penyimpanan gas LPG tersebut [2].

Gas LPG yang ada di dalam tabung, wujudnya berupa zat cair dan sebagian adalah uap. Rasio antara volume gas bila menguap dengan gas dalam keadaan cair bervariasi tergantung komposisi, tekanan dan temperatur, tetapi biasanya sekitar 250:1 [3]. Ketika tabung LPG mengalami kebocoran, cairan LPG akan keluar dengan cepat dan menjadi gas yang mudah meledak jika terpicu percikan api [4]. 


\section{METODE}

Kebakaran merupakan suatu peristiwa yang tidak dikehendaki oleh setiap manusia. Kebakaran dapat mengakibatkan kerugian yang tidak sedikit, baik kerugian material maupun kerugian jiwa yang ditimbulkan [5]. Dari hasil pengamatan ternyata banyak pengguna gas LPG yang tidak mengetahui cara mengatasi terjadinya kebocoran pada gas LPG tersebut, akibatnya sering terjadi ledakan dan kebakaran karena gas LPG [6]. Menurut hasil survei yang dilakukan oleh Badan Standarisasi Nasional (BSN) tentang penyebab kebocoran gas, pada umumnya kebocoran gas terjadi karena adanya masalah pada selang, regulator, katup, kompor dan tabung [7]. Untuk mengurangi resiko kebakaran akibat kebocoran gas LPG, maka diperlukan suatu alat yang dapat mendeteksi lebih awal jika terjadi kebocoran gas atau kebakaran yang dapat dipantau dari jarak jauh. Dengan demikian, pengguna dapat mengantisipasi masalah tersebut sehingga tidak menimbulkan korban jiwa.

Perangkat untuk mendeteksi terjadinya kebocoran gas LPG dan kebakaran menggunakan sensor gas dan sensor api seperti pada penelitian [8]. Notifikasi pesan ditampilkan di Liquid crystal display (LCD) yang terpasang di tempat penympianan gas. Kekurangan perangkat ini adalah notifikasi pesan kebocoran gas maupun kebakaran hanya bersifat lokal dan tidak dapat dipantau dalam jarak yang jauh. Beberapa penelitian dilakukan untuk melengkapi kekurangan perangkat di atas. Perangkat deteksi kebocoran gas dan kebakaran dilengkapi dengan teknologi yang dapat menyampaikan notifikasi pesan secara jarak jauh. Teknologi yang sekarang ini sedang banyak diterapkan adalah teknologi Internet of Things. Dengan teknologi ini, pesan dari perangkat akan dikirimkan ke pengguna melalui jaringan internet [1][5][9][10]. Di bagian pengguna, pesan informasi dapat ditampilkan melalui website [5][9] maupun aplikasi android pada smartphone [1]. Dari penelitian-penelitian sistem monitoring kebocoran gas LPG menggunakan teknologi Internet of Things di atas, pengujian terhadap layanan kualitas komunikasi data belum dilakukan oleh para peneliti. Padahal, salah satu analisis yang penting saat menggunakan teknologi Internet of Things adalah layanan kualitas komunikasi data.

Berdasarkan permasalah di atas, maka pada penelitian ini akan dibahas tentang implementasi teknologi Internet of Things untuk memantau kebocoran gas LPG dan kebakaran menggunakan database pada Google Firebase. Layanan kualitas komunikasi data merupakan salah satu parameter yang diuji yaitu parameter waktu tunda (delay) dan throughput. Perangkat yang digunakan pada sistem ini diantara lain sensor MQ-6, flame sensor, NodeMCU ESP 8266 V3, relay, kipas, buzzer. Google Firebase dan smartphone. Sistematika penulisan sebagai berikut: Bab I Pendahuluan, Bab II Metode, Bab III Hasil dan Pembahasan, Bab IV Kesimpulan.
Tahapan penelitian yang dilakukan sesuai kaidah ilmiah. Tahap awal adalah melakukan studi Pustaka dari topik penelitian yang telah ditentukan sebelumnya. Kemudian dari hasil studi Pustaka tersebut, maka dapat ditentukan rumusan masalah dari penelitian. Dari rumusan masalah tersebut dirancanglah suatu sistem yang dapat digunakan untuk mengatasi masalah penelitian tersebut. Sistem yang dirancang tersebut kemudian diuji pada lingkungan yang sesuai dan tahap selanjutnya adalah menarik kesimpulan dari penelitian tersebut. Adapun alat dan bahan penelitian yang digunakan antara lain sensor gas MQ-6, flame sensor sebagai input sistem. NodeMCU ESP 8266 sebagai pengolah data, dan buzzer, kipas, dan aplikasi android sebagai output sistem. Sedangkan tools yang digunakan seperti Wireshark, dan Google Firebase.

\section{A.Diagram Blok Sistem}

Diagram blok dari sistem yang dirancang seperti ditunjukkan pada Gambar 1. Pada gambar tersebut terdapat beberapa bagian, yaitu Input, Proses dan Output. Pada bagian input terdapat 2 sensor yang digunakan untuk mengambil data kebocoran gas LPG dan kebakaran. Sensor pertama adalah sensor gas MQ6 yang digunakan untuk mengukur kadar gas pada ruangan kemudian sensor kedua yaitu sensor api yang digunakan untuk mendeteksi ada atau tidaknya api. Bagian kedua yaitu proses yang terdiri dari sebuah mikrokontroler sebagai pengolah data yang didapatkan dari bagian input. Mikrokontroler akan memberikan perintah kepada buzzer, relay, kipas dan smartphone sebagai output. Pada output terdapat beberapa keadaan, yaitu memberikan perintah buzzer agar berbunyi, relay sebagai saklar untuk menggerakkan kipas dan hasil data akan diunggah ke fitur realtime database pada google firebase menggunakan jaringan internet kemudian data pada database akan ditampilkan pada smartphone melalui aplikasi android.

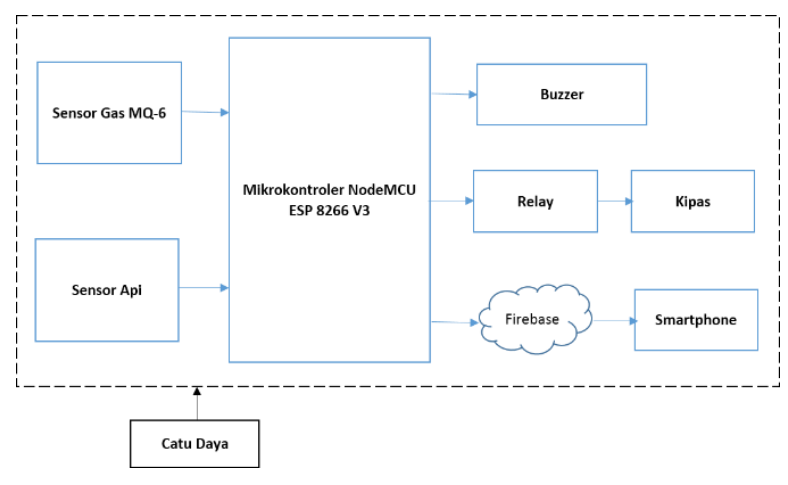

Gambar 1. Diagram blok Sistem

\section{B. Rangkaian Sensor MQ-6}

Paga Gambar 2 ditunjukkan rangkaian sensor gas MQ-6. Pada rangkaian tersebut, Vcc terhubung dengan tegangan Vusb, keluaran sensor terhubung dengan pin A0 dan GND ke ground. Keluaran sensor berupa 
keluaran analog. Untuk mendapatkan nilai PPM dapat menggunakan persamaan (1) dan (2).

$X=\frac{\text { Range }}{\text { Totalbit }}$

$\mathrm{PPM}=\mathrm{X} \times$ Keluaran ADC

Pembacaan ADC pada NodeMCU menggunakan 10 bit, rentang output yang dihasilkan yaitu 2 pangkat 10 $=1024$. Sensor MQ-6 mempunyai range deteksi antara 200 - 10000 PPM sehingga total range yaitu 9800.

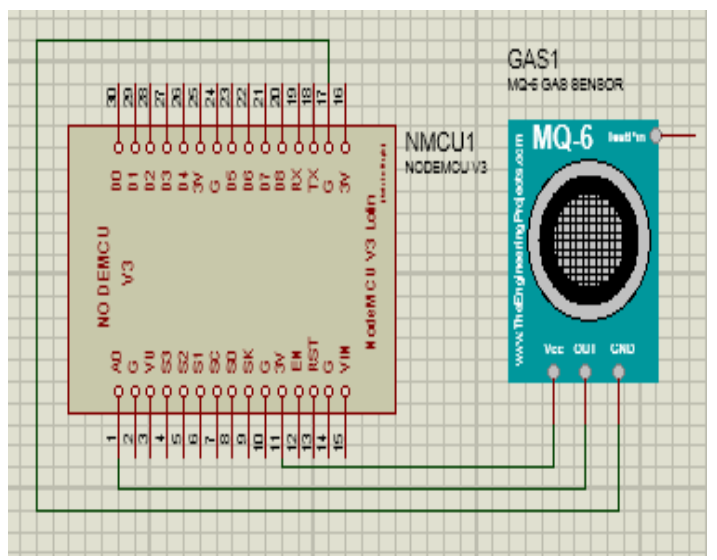

Gambar 2. Rangkaian Sensor MQ-6

\section{Rangkain Flame Sensor}

Pada Gambar 3 ditunjukkan rangkaian flame sensor. Pada rangkaian flame sensor, Vcc terhubung dengan tegangan 3.3 Volt, pembacaam sensor menggunakan pin D0, GND ke ground.

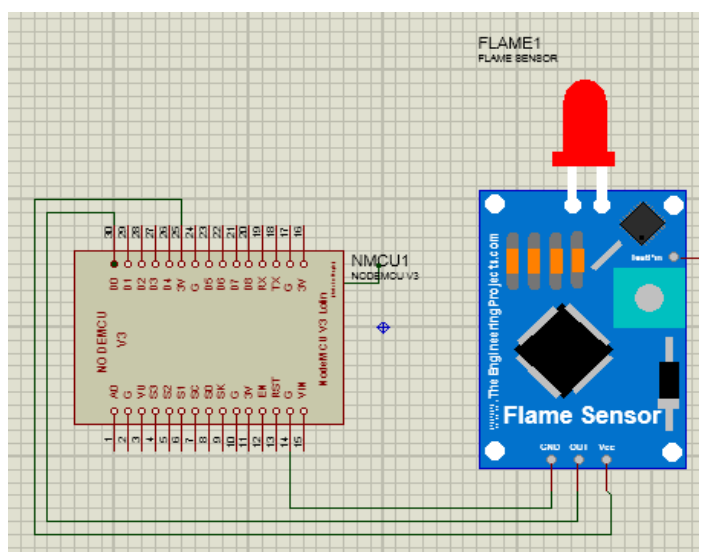

Gambar 3. Rangkaian Flame Sensor

\section{Rangkaian Keseluruhan}

Pada Gambar 4 ditunjukkan rangkaian keseluruhan dari sistem pemantauan kebocoran gas LPG dan kebakaran berbasis internet of things. Rangkaian pada Gambar 4 merupakan integrasi antara komponen yang satu dengan komponen-komponen yang lain yang terhubung ke NodeMCU sebagai mikropengendali. NodeMCU terhubung dengan sensor gas MQ-6 pada port A0, flame sensor pada port D0, buzzer pada port D1 dan modul relay pada port D7.

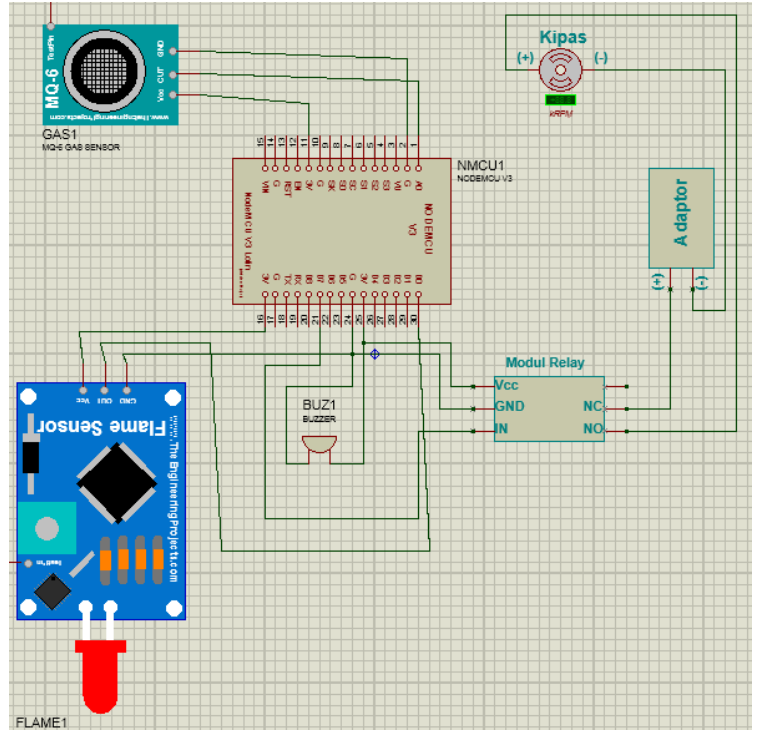

Gambar 4. Rangkaian keseluruhan

\section{E. Pengaturan Google Firebase}

Google Firebase digunakan untuk database dari data sensor. Firebase merupakan penyedia layanan realtime database dan backend yang saat ini dimiliki oleh Google. Salah satu fitur yang dimiliki oleh Firebase adalah Firebase Realtime Database. Ini adalah fitur yang memberikan sebuah NoSQL database yang dapat diakses secara realtime oleh pengguna aplikasi.

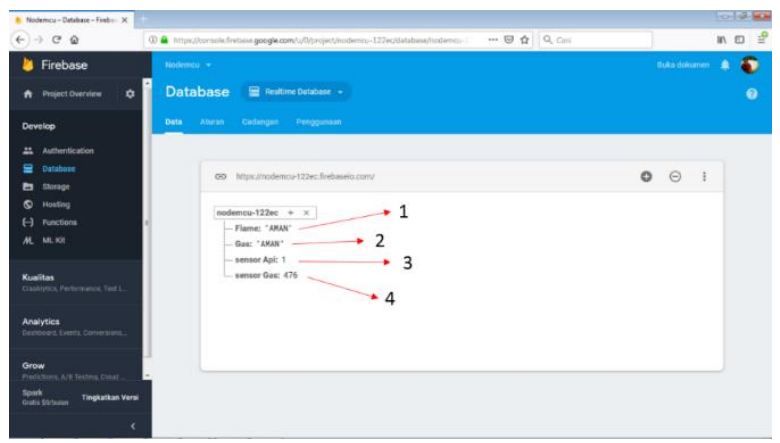

Gambar 5. Tampilan Google Firebase

Pada Gambar 5 ditunjukkan tampilan realtime database untuk sistem pemantauan kebocoran gas LPG dan kebakaran yang telah dibuat, pada tampilan tersebut terdapat 4 buah data dari keluaran sensor yaitu Flame, Gas, sensor api dan sensor gas. Pada nomor 1 merupakan tampilan data untuk indikator kondisi Aman atau Bahaya dari data yang didapatkan pada flame sensor. Pada nomor 2 merupakan tampilan untuk indikator Aman atau bahaya kebocoran gas dari data sensor MQ-6. Pada nomor 3 merupakan hasil keluaran digital dari flame sensor, apabila menunjukan angka 1 berarti sensor tidak mendeteksi adanya api(Aman) sedangkan apabila keluaran dari sensor berupa angka 0 menandakan bahwa flame sensor mendeteksi adanya api(Bahaya). Pada nomor 4 merupakan hasil keluaran analog dari sensor gas MQ-6 yang merupakan jumlah konsentrasi gas pada ruangan. Data dari relatime 
database inilah yang kemudian ditampilkan pada aplikasi android pada smartphone yang telah dibuat.

\section{F. Diagram Alir Pemrograman Sistem}

Pada Gambar 6 ditunjukkan diagram alir program yang tertanam di NodeMCU ESP8266, sedangkan pada Gambar 7 ditunjukkan diagram alir program untuk perancangan aplikasi android pada smartphone.

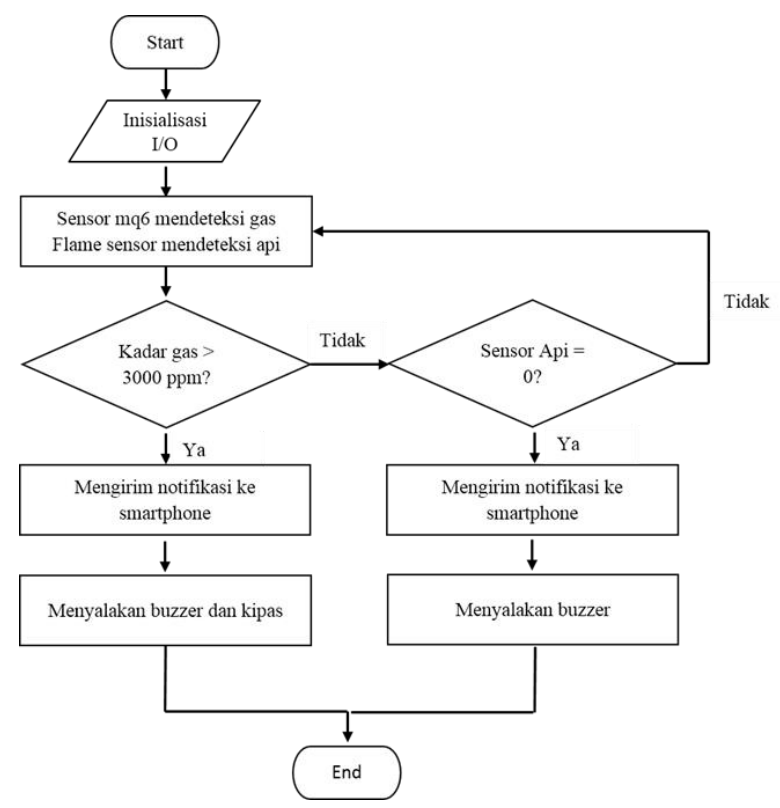

Gambar 6. Diagram alir program pada NodeMCU ESP8266

Diagram alir sistem pada Gambar 6 dimulai dari inisialisasi input \& output. Inisialisasi ini bertujuan untuk menentukan pin input atau pin output yang akan digunakan dalam perancangan. Selanjutnya yaitu pembacaan sensor gas dan sensor api. Apabila kadar gas melebihi batas yang telah ditentukan, yaitu lebih dari $3000 \mathrm{ppm}$ maka notifikasi akan dikirimkan ke smartphone menandakan bahwa adanya kebocoran gas dan kemudian buzzer dan kipas akan dinyalakan. Namun apabila kadar gas tidak melebihi 3000 ppm program akan mengecek sensor api apakah bernilai 0 yang berarti mendeteksi adanya api atau bernilai 1 yang berarti tidak terdeteksi adanya api. Apabila sensor api = 0 maka akan mengirimkan notifikasi ke smartphone bahwa telah terdeteksi adanya api dan kemudian menyalakan buzzer. Namun apabila sensor api $=1$ maka sistem akan kembali ke tahap pendeteksian gas dan api.

Sedangkan pada diagram alir sistem aplikasi android seperti yang ditunjukkan pada Gambar 7, dimulai dari mencari koneksi wifi, selanjutnya apabila dapat berhasil terhubung ke wifi yang telah ditentukan dan terdapat koneksi internet maka aplikasi yang ada pada smartphone akan menerima data dari mikrokontroler. Apabila kadar gas melebihi batas maka akan muncul notifikasi bahaya kebocoran gas pada smartphone.

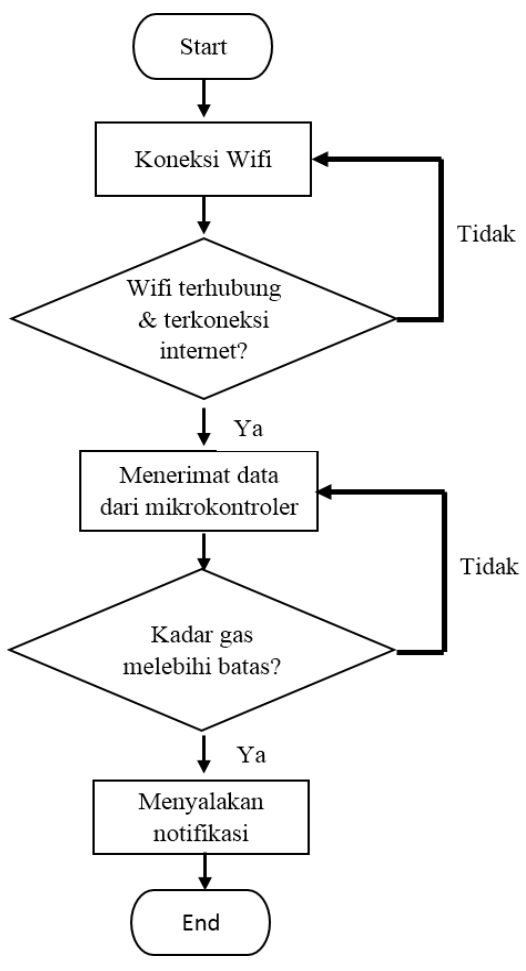

Gambar 7. Diagram alir program pada aplikasi android

\section{G. Tahap Pengujian}

Pengujian dilakukan untuk mengetahui kinerja dari masing-masing sub-sistem yang dirancang, kemudian baru menguji sistem keseluruhan. Berikut ini adalah sub-sistem yang akan diuji dalam penelitian ini.

\section{Pengujian Sensor Gas MQ-6}

2. Pengujian Sensor api (Flame sensor)

3. Pengujian sistem keseluruhan

4. Pengujian Waktu tunda (delay)

5. Pengujian Throughput

\section{HASIL DAN PEMBAHASAN}

\section{A. Integrasi Perangkat Keras Sistem}

Pada Gambar 8 ditunjukkan tampilan integrasi perangkat keras sistem. Perangkat keras meliputi NodeMCU, sensor gas MQ-6, flame sensor, buzzer, modul relay 1 channel yang terhubung dengan kipas.

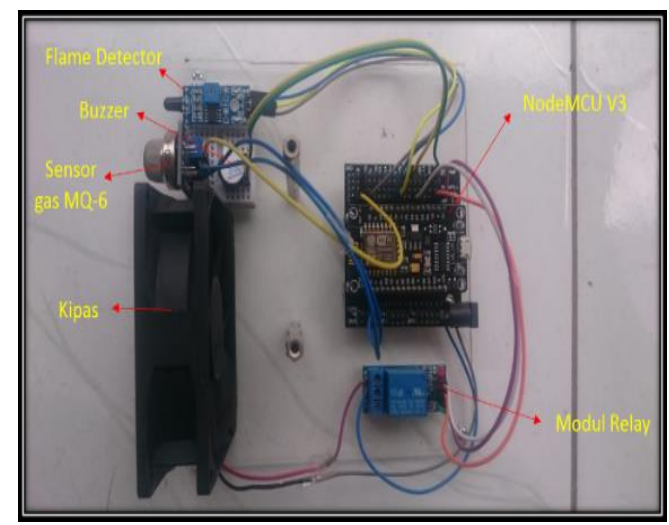

Gambar 8. Integrasi perangkat keras sistem 


\section{B. Hasil Perancangan Aplikasi Andorid}

Pada Gambar 9 ditunjukkan tampilan rancangan aplikasi android. Pada tampilan tersebut terdapat dua jenis informasi yang bisa didapat, yang pertama yaitu merupakan informasi kadar gas atau kensentrasi gas di udara dan yang kedua yaitu informasi ada tidaknya api yang terdeteksi oleh flame sensor.

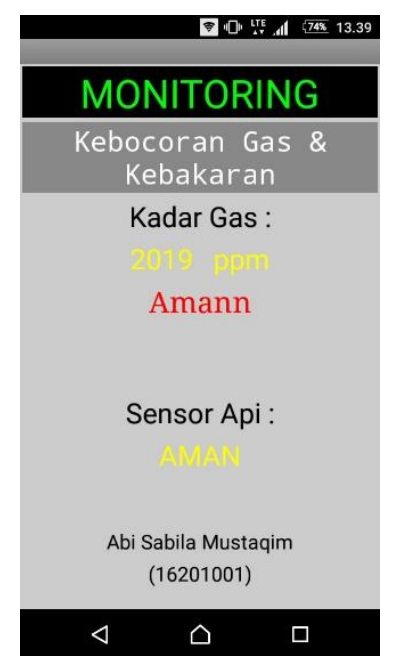

Gambar 9. Tampilan aplikasi android

\section{Pengujian Kadar Gas LPG Menggunakan Sensor MQ-6}

Pada pengujian sensor gas MQ-6 dibuat jarak antara sensor gas dengan gas yang dibocorkan, jarak tersebut bervariasi mulai dengan jarak $10 \mathrm{~cm}$ hingga jarak 60 $\mathrm{cm}$. Untuk gas yang digunakan dalam pengujian yaitu menggunakan gas yang mengandung butana. Pengujian dilakukan dengan membandingkan kondisi udara sebelum adanya kebocoran gas dan kondisi udara setelah adanya kebocoran gas. Pada Gambar 10 ditunjukkan hasil pengujian sensor gas MQ-6.

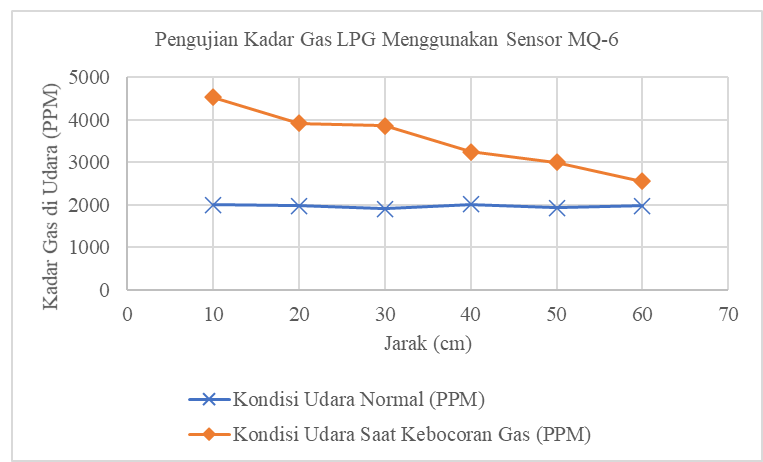

Gambar 10. Hasil Pengujian Kadar Gas LPG Menggunakan Sensor MQ-6

Dari grafik pada Gambar 10 ditunjukkan bahwa semakin jauh jarak sensor gas dengan sumber kebocoran gas maka kadar gas LPG akan semakin turun. Sehingga penempatan sensor MQ-6 tidak boleh terlalu jauh dari sumber gas LPG, yaitu sekitar $10 \mathrm{~cm}$.

\section{Pengujian Flame Sensor}

Pada pengujian flame sensor, perlakukannya hampir sama seperti pada pengujian sensor gas yaitu pengujian dilakukan dengan variasi jarak antara flame sensor dengan sumber api. Variasi jarak mulai dari jarak $10 \mathrm{~cm}$ hingga jarak $150 \mathrm{~cm}$. Untuk api yang digunakan pada pengujian yaitu menggunakan api kecil pada sebuah lilin. Pada Tabel 1 ditunjukkan hasil pengujian flame sensor.

Tabel 1. Hasil Pengujian Flame Sensor

\begin{tabular}{ccc}
\hline No & $\begin{array}{c}\text { Jarak Api } \\
(\mathbf{c m})\end{array}$ & Keterangan \\
\hline 1 & 10 & Tedeteksi \\
2 & 20 & Tedeteksi \\
3 & 30 & Tedeteksi \\
4 & 40 & Tedeteksi \\
5 & 50 & Tedeteksi \\
6 & 60 & Tedeteksi \\
7 & 70 & Tedeteksi \\
8 & 80 & Tedeteksi \\
9 & 90 & Tedeteksi \\
10 & 100 & Tedeteksi \\
11 & 110 & Tedeteksi \\
12 & 120 & Tedeteksi \\
13 & 130 & Tidak Terdeteksi \\
14 & 140 & Tidak Terdeteksi \\
15 & 150 & Tidak Terdeteksi \\
\hline & & \\
\hline 15 &
\end{tabular}

Dari hasil pengujian dapat diperoleh bahwa flame sensor hanya dapat mendeteksi adanya api kecil sampai jarak $120 \mathrm{~cm}$, setelah jarak tersebut maka flame sensor tidak dapat mendeteksi adanya api.

\section{E. Pengujian Sistem Keseluruhan}

Pengujian rangkaian keseluruhan dilakukan untuk mengetahui apakah sistem yang telah dibuat dapat bekerja sesuai dengan yang direncanakana atau tidak. Pengujian ini dilakukan dengan cara mendeteksi adanya gas yang bocor pada sensor MQ-6 dan mendeteksi adanya api pada flame sensor. Pada saat setiap sensor gas MQ-6 mendeteksi kebocoran gas maka indikator yang berfungsi adalah buzzer, kipas dan aplikasi android. Sedangkan pada saat setiap flame detector mendeteksi adanya api maka indikator yang berfungsi yaitu buzzer dan aplikasi android. Hasil pengujian seluruh komponen ditunjukkan pada Tabel 2 dan Tabel 3.

\section{F. Pengujian Waktu Tunda (Delay)}

Proses pengujian delay dilakukan dengan pengujian pengiriman data dari sisi tx ke sisi rx. Untuk sisi tx yaitu NodeMCU sebagai access point dan pada sisi rx yaitu laptop yang sudah terinstal aplikasi Wireshark. Pada pengujian delay kali ini dilakukan menggunakan jarak dari 1 meter hingga 6 meter, setiap meternya dilakukan sebanyak 5 kali pengujian dan setiap pengujiannya dilakukan selama satu menit, sehingga seluruh 
pengujian dilakukan sebanyak 30 kali. Pada Gambar 11 ditunjukkan hasil pengujian delay berdasarkan jarak antara NodeMCU ke Access Point.

Tabel 2. Hasil Pengujian Keseluruhan Rangkaian Saat Sensor MQ-6 aktif

\begin{tabular}{cccccc}
\hline No & $\begin{array}{c}\text { KadarGas } \\
(\text { PPM })\end{array}$ & Kondisi & Buzzer & Kipas & $\begin{array}{c}\text { Tampilan } \\
\text { Aplikasi }\end{array}$ \\
\hline 1 & $<3000$ & Aman & Mati & Mati & Aman \\
2 & $>=3000$ & Bahaya & Menyala & Menyala & Berbahaya \\
\hline
\end{tabular}

Tabel 3. Hasil Pengujian Keseluruhan Rangkaian Saat Flame Sensor aktif

\begin{tabular}{cccccc}
\hline No & $\begin{array}{c}\text { Terdeteksi } \\
\text { Api }\end{array}$ & Kondisi & Buzzer & Kipas & $\begin{array}{c}\text { Tampilan } \\
\text { Aplikasi }\end{array}$ \\
\hline 1 & Tidak & Aman & Mati & Mati & Aman \\
2 & Ya & Bahaya & Menyala & Mati & Berbahaya \\
\hline
\end{tabular}

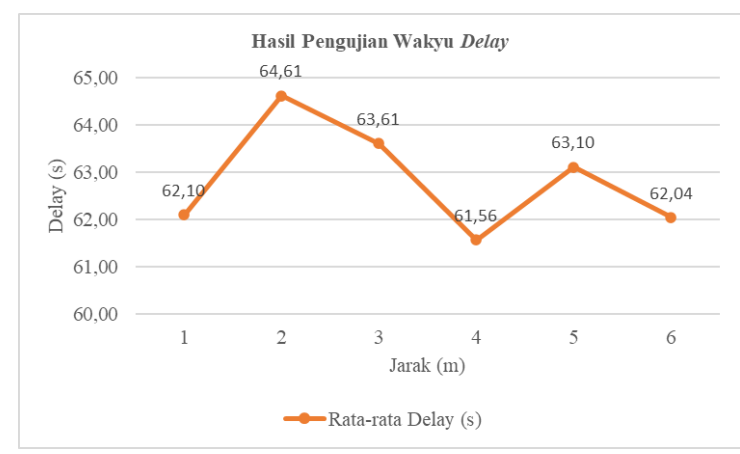

Gambar 12. Hasil Pengujian Waktu Delay

Pada pengujian delay didapat nilai rata-rata tertinggi dari waktu delay yaitu 64.61 detik pada jarak pengukuran 2 meter dan rata-rata delay terendah 61.562 detik pada jarak pengukuran 4 meter. Pada pengujian ini dapat diambil kesimpulan bahwa jarak tidak terlalu mempengaruhi terhadap besarnya nilai delay.

\section{G. Pengujian Throughput}

Pengujian throughput bertujuan untuk mengetahui banyaknya data yang terkirim dalam 1 detik. Pengujian throughput dilakukan dengan memperhatikan jumlah paket data yang dikirimkan saat itu. Pada Gambar 12 ditunjukkan hasil pengujian throughput.

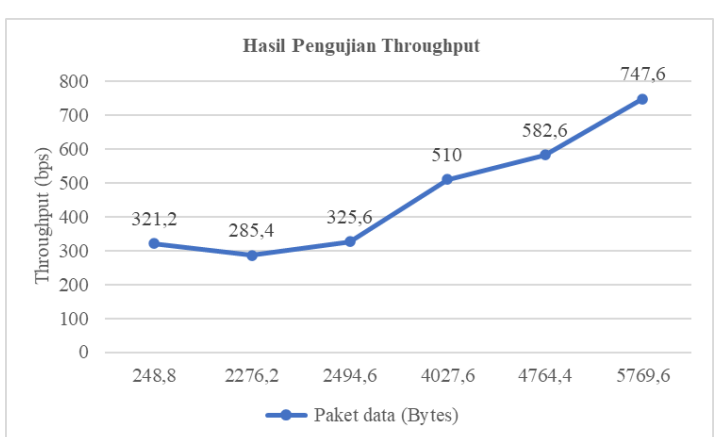

Gambar 12. Hasil Pengujian Throughput
Dari grafik pada Gambar 13 tersebut menunjukkan bahwa semakin besar ukuran paket data yang terkirim maka nilai throughput juga akan semakin besar. Nilai throughput tertinggi pada nilai 747,6 bps dan nilai throughput terendah pada nilai 285,4 bps.

\section{KESIMPULAN}

Pengujian keseluruhan sistem dapat bekerja dengan baik dan berhasil melakukan setiap prosesnya dengan benar mulai dari pembacaan sensor, menyalakan kipas dan buzzer ketika terjadi kebocoran gas, pengiriman data ke database firebase sampai menampilkannya pada aplikasi android. Jarak yang direkomendasikan antara sensor gas MQ-6 dan Flame sensor dengan sumber sekitar $10 \mathrm{~cm}$, semakin jauh jaraknya maka akan semakin menurun pembacaan sensornya. Pada pengujian waktu delay menunjukkan bahwa jarak tidak begitu berpengaruh signifikan terhadap waktu delay, nilai tertinggi waktu delay adalah 64,61 detik dan nilai terendahnya adalah 61, 562 detik. Pada pengujian nilai throughput, besarnya paket data yang dikirimkan akan mempengaruhi besarnya throughput. Nilai tertinggi throughput adalah 747,6 bps dan nilai terendahnya adalah 285,4 bps.

\section{UCAPAN TERIMA KASIH (ACKNOWLEDGEMENT)}

Ucapan terima kasih ditujukan kepada Program Studi D3 Teknik telekomunikasi Institut Teknologi Telkom Purwokerto yang telah mendorong dan mendukung penelitian ini.

\section{REFERENSI}

[1] R. W. S. Muhammad, "Smartbox Pendeteksi Dan Penanggulangan Kebocoran Tabung Gas Lpg Berbasis Arduino Mega 2560," Universitas Muhammadiyah Surakarta, 2014

[2] M. F. Putra, A. H. Kridalaksana, and Z. Arifin, "Rancang Bangun Alat Pendeteksi Kebocoran Gas LPG Dengan Sensor Mq-6 Berbasis Mikrokontroler Melalui Smartphone Android Sebagai Media Informasi,” Inform. Mulawarman J. Ilm. Ilmu Komput., vol. 12, no. 1, p. 1, 2018.

[3] Sriwati, "Sistem Proteksi Dini Kebocoran Gas LPG (Liquefied Petroleum Gas) Berbasis Mikrokontroller ATMega 16," Seminar Nasional dan Expo Teknik Elektro 2017, hal. 143-150

[4] M. W. Putri, M. Hamdan, and Hendro, "Detektor LPG Menggunakan Sensor MQ-6 Berbasis Mikrokontroler ATMega 328P,” Institut Teknologi Bandung, 2017

[5] P. Studi, T. Informatika, and F. T. Industri, "Rancang Bangun Sistem Monitoring Deteksi Dini Kebakaran Dengan Fitur Gps," 2018.

[6] H. L. Afrisyah, "Desain Alat Deteksi Kebocoran Gas Lpg (Butana) Berbasis Atmega328 Dengan Monitoring Android," Universitas Sumatera Utara, 2016. 
Abi Sabila Mustaqim dkk : Implementasi Teknologi Internet of Things Pada Sistem Pemantauan Kebocoran Gas LPG dan Kebakaran Menggunakan Database Pada Google Firebase

[7] R. L. Ismai, J. Endro, and S. Suryono, "Rancang bangun sistem pengaman kebocoran gas LPG ( Liquefied Petroleum Gas ) menggunakan mikrokontroler," Youngster Physics Journal, vol. 6, no. 4, 2017.

[8] D. D. Hutagalung, "Rancang Bangun Alat Pendeteksi Kebocoran Gas Dan Api Dengan Menggunakan Sensor Mq2 Dan Flame Detector," Jurnal Rekayasa Informasi” vol. 7, no. 2, 2018.

[9] D. Samudera and A. Sugiharto, "Sistem Peringatan dan Penanganan Kebocoran Gas Flammable Dan Kebakaran
Berbasis Internet of Things ( Iot )," Jurnal TeknoSains, vol. 01, no. 01, pp. 1-13, 2018.

[10] A. Faqih Rifa'i, "Sistem Pendeteksi Dan Monitoring Kebocoran Gas ( Liquefied Petrolum Gas ) Berbasis Internet of," Jurnal Tek. Informatika, vol. 1, no. 1, pp. 5-13, 2016. 